\title{
FIRST DETECTION OF VANCOMYCIN RESISTANT Enterococcus faecium IN LATVIA
}

\author{
Dace Rudzìte*, Arta Olga Balode ${ }^{\star \star, \star \star *}$, Uga Dumpis ${ }^{\star * \star \star \star \star}$, Edvīns Miklaševičs ${ }^{\star *, \star \star \star}$ \\ * Rīga Eastern Clinical University Hospital, Hipokrāta iela 2, Rīga, LV-1038, LATVIA \\ ** Department of Molecular Biology and Genetics, Pauls Stradiṇš Clinical University Hospital, Pilsoṇu iela 13, Rĩga, LV-1002, LATVIA; \\ e-mail: edvins.miklasevics@stradini.Iv \\ *** Rīga Stradiṇš University, Dzirnavu iela 16, Rīga, LV-1007, LATVIA \\ **** Faculty of Medicine, University of Latvia, Šarlotes iela 1a, Rĩga, LV-1001, LATVIA
}

Communicated by Andrejs Ërglis

\begin{abstract}
Enterococci have become one of the most important nosocomial pathogens in advanced treatment facilities. Though they are not considered as very pathogenic bacteria, their high levels of antimicrobial resistance are the subject of major concern. Particularly epidemiologically important are vancomycin-resistant enterococci (VRE) due to high risk of transmission of vancomycin resistance genes to staphylococci. We describe the first outbreak of VRE in a Latvian multidisciplinary hospital.
\end{abstract}

Key words: vancomycin, enterococci, nosocomial infections.

While enterococci are well known to cause community-acquired infections, e.g. urinary tract infection and endocarditis, since the mid 1970s, their importance has grown as a cause of nosocomial infections (Maki and Agger, 1988). While not as virulent as other Gram-positive bacteria, enterococci can cause different clinical syndromes: endocarditis, bacteraemia, meningitis, wound and urinary tract infections, peritonitis and intra-abdominal abscesses. The majority of clinical enterococcal infections are caused by Enterococcus faecalis (up to $80 \%$ of clinical isolates), and Enterococcus faecium in most of the other cases (Huycke et al., 1998). Enterococci are intrinsically resistant to a broad range of antibiotics including cephalosporins, penicillins, sulphonamides and low concentrations of aminoglycosides (Gold and Moellering, 1996). The resistance of enterococci is increasing disturbingly. Due to mutations and/or exchange of mobile genetic elements (plasmids, transposons) enterococci have acquired resistance to high concentrations of $\beta$-lactams (via penicillin binding proteins or $\beta$-lactamases) and aminoglycosides, glycopeptides (vancomycin and teicoplanin), tetracycline, erythromycin, fluoroquinolones, rifampin, chloramphenicol, fusidic acid and nitrofurantoin (Gold and Moellering, 1996; Mundy et al., 2000). The first published reports on vancomycin-resistant enterococci (VRE) originated from Europe (Uttley et al., 1988; Leclercq et al., 1988) almost 30 years after the introduction of vancomycin in the USA. Since then the percentage of VRE has climbed remarkably and in some European countries the proportion of invasive isolates resistant to vancomycin reached $10 \%$ (UK, Ger- many, Italy), or even more than 25\% (Ireland, Portugal, Greece) in 2007 (Anonymous, 2007). Thus, VRE are often resistant to multiple antibiotics, have a broad geographic distribution and have become a significant agent of nosocomial infections.

Glycopeptides and $\beta$-lactams essentially block the same transpeptidation reaction, which is necessary for cross-linkage of peptidoglycanchains, but using different mechanisms: $\beta$-lactams bind, and thus, inactivate enzyme glycopeptide transpeptidase (Therrien and Levesque, 2000) whereas vancomycin binds the corresponding substrate D-Ala-D-Ala peptide - and eliminates it from reaction (Reynolds, 1989). Six types of glycopeptide resistance operons have been described and they are recognised by the resistance ligase (vanA,vanB, vanC, vanD, vanE and vanG). E. faecium and E. faecalis predominantly possess VanAand VanB-type resistance. Enterococci harbouring the vanA operon display high level resistance to both vancomycin and teicoplanin whereas strains carrying the van $B$ operon are resistant to variable levels of vancomycin but not teicoplanin (Arthur et al., 1996). The presence of these operons ensures a new biochemical pathway in which regular D-Ala-D-Ala peptide to which glycopeptides bind is replaced by D-Ala-D-lactate. As a result affinity between glycopeptide and a new substrate is decreased more than 1000 fold and the antibiotic becomes ineffective.

In addition to the treatment of multidrug-resistant enterococcal infections another challenge is the organism's potential to serve as a reservoir for resistance genes. In the labo- 
ratory, resistance to glycopeptide antibiotics has been transferred between enterococcal species and from enterococci to other gram-positive organisms, including streptococci, Listeria monocytogenes, and Staphylococcus. aureus (Leclercq et al., 1989; Noble et al., 1992). Isolation of the first VRE isolates in Latvia is described in this paper.

Identification of bacterial isolates and determination of their antimicrobial resistance were performed on Vitek 2 (Biomerieux). Molecular verification of the isolate species and typing of the van operon was conducted by multiplex PCR (Depardieu et al., 2004).

The first Latvian VRE was isolated from two patients stationed at the Riga Eastern Clinical University Hospital in November - December 2006. Patient 1 was a 41-year-old male with a rectal injury, secondary wound infection and bilateral pneumonia. Initially, coagulase negative staphylococcus, Escherichia coli, Citrobacter freundii and vancomycin sensitive Enterococcus faecium were isolated from the surgical site. Imipenem, ceftriaxone, metronidazole and vancomycin were prescribed. Two weeks after the first application of vancomycin, a vancomycin-resistant Enterococcus faecium was isolated from the infected wound. Patient 2 was a 74-year-old woman with schizophrenia, drug overdose and ventilator-associated pneumonia. Vancomycinresistant Enterococcus faecium, Kl. pneumonia and Enterobacter cloacae were isolated from broncho-alveolar lavage. Both patients for some period were stationed at ICU. Enteroccoci were isolated from both patients and first identified on Vitek 2 as Enterococcus faecium and this identification was further verified by PCR targeting the $d d l$ (D-Ala:D-Ala ligase) gene of E. faecium (Fig. 1).

Antimicrobial susceptibility was determined on Vitek 2 using a Gram Positive Susceptibility Card. Both strains displayed an identical resistance pattern: resistant to ampicillin, gentamicin, streptomycin, ciprofloxacin, erythromycin, clindamycin, teicoplanin (MIC32 mg/l), vancomycin (MIC256 mg/l) and trimethoprim/sulfamethoxazole, and susceptible to linezolid (MIC $2 \mathrm{mg} / \mathrm{l}$ ). To investigate the mechanism responsible for the vancomycin resistance of these strains, a multiplex PCR (Depardieu et al., 2004) was used to detect the six types of glycopeptide resistance. Analyses of the amplification products revealed a band corresponding to the vanA operon in both tested isolates (Fig. $1)$. This result is in agreement with the antibiotic susceptibility test, as it is known that the vanA operon provides resistance to high levels of vancomycin and teicoplanin.

To our knowledge, this was the first outbreak of VanA-type vancomycin-resistant enterococcus in Latvia. Apparently, in the first case resistance was selected by long-term treatment with vancomycin, or acquired from another patient that remained unidentified. Later, the same strain of bacteria was transmitted to the second patient who was hospitalised in the same department at the same time. Strict infection control measures were employed later and no other secondary cases were reported later at the responsible department. In the future, routine microbiological surveillance of Enteroc-

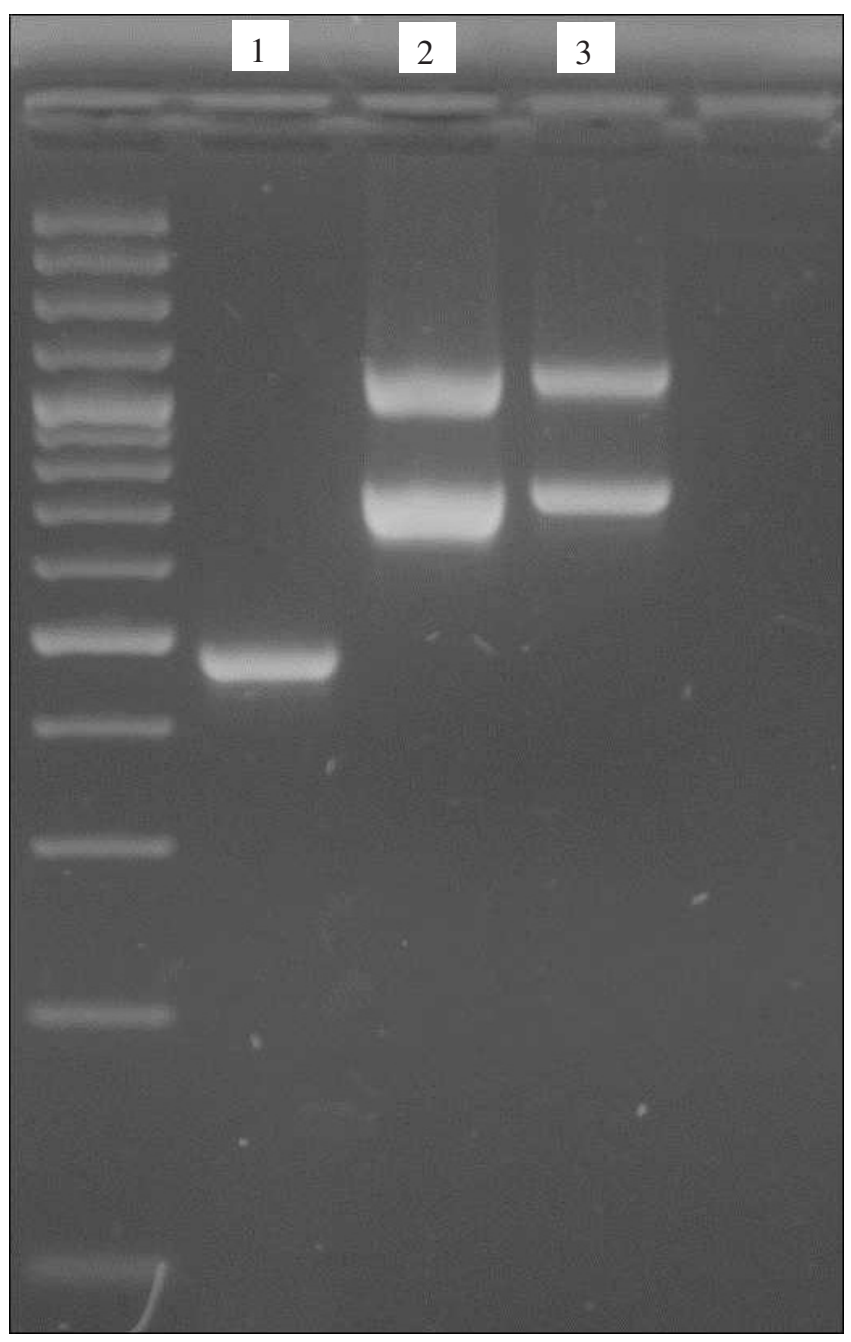

Fig. 1. Separation of the amplification products of multiplex PCR. 1, the $d d l$ gene of E. faecalis; 2, sample from Patient 1; 3, sample from Patient 2. In 2 and 3 , the upper band corresponds to the $d d l$ gene of E. faecium and the lower band, to the vanA operon.

cocus faecium and Enterococcus faecalis resistance as infection control is recommended to early identify outbreaks of VRE.

\section{ACKNOWLEDGEMENTS}

The work was supported by the National Research Programme in Medicine 2006-2009, project No. 12, "Elaboration of approaches for modern diagnostics, epidemiology, prevention and therapy of the most clinically important multidrug resistant bacteria”.

\section{REFERENCES}

Arthur, M., Reynolds, P., Courvalin, P. (1996). Glycopeptide resistance in enterococci. Trends Microbiol., 4, 401-407.

Depardieu, F., Perichon, B., Courvalin, P. (2004). Detection of the van alphabet and identification of enterococci and staphylococci at the species level by multiplex PCR. J. Clin. Microbiol., 42, 5857-5860.

Gold, H.S., Moellering, R.C. Jr. (1996). Antimicrobial-drug resistance. New Engl. J. Med., 335, 1445-1453. 
Huycke, M.M., Sahm, D.F., Gilmore, M.S. (1998). Multiple-drug resistant enterococci: The nature of the problem and an agenda for the future. Emerg. Infect. Dis., 4, 239-249.

Leclercq, R., Derlot, E., Duval, J., Courvalin, P. (1988). Plasmid-mediated resistance to vancomycin and teicoplanin in Enterococcus faecium. New Engl. J. Med., 319, 157-161.

Leclercq, R., Derlot, E., Weber, M., Duval, J., Courvalin, P. (1989). Transferable vancomycin and teicoplanin resistance in Enterococcus faecium. Antimicrob. Agents Chemother., 33, 10-15.

Maki, D.G., Agger, W.A. (1988). Enterococcal bacteremia: Clinical features the risk of endocarditis and managment. Medicine, 67, 248-269.

Received 11 July 2009
Mundy, L.M., Sahm, D.F., Gilmore, M. (2000). Relationships between enterococcal virulence and antimicrobial resistance. Clin. Microbiol. Rev., 13, 513-522.

Noble, W.C., Virani, Z., Cree, R.G.A. (1992). Co-transfer of vancomycin and other resistance genes from Enterococcus faecalis NCTC 12201 to Staphylococcusaureus. FEMS Microbiol Lett., 93, 195-198.

Reynolds, E. (1989). Structure, biochemistry and mechanism of action of glycopeptide antibiotics. Eur. J. Clin. Microbiol. Infect. Dis., 8, 943-950.

Therrien, C., Levesque, R.C. (2000). Molecular basis of antibiotic resistance and beta-lactamase inhibition by mechanism-based inactivators: Perspectives and future directions. FEMS Microbiol Rev., 24, 251-262.

Uttley, A.H., Collins, C.H., Naidoo, J., George, R.C. (1988). Vancomycinresistant enterococci. Lancet, 1, 57-58.

\section{PIRMAIS DOKUMENTĒTAIS PRET VANKOMICĪNU REZISTENTO Enterococcus faecium GADĪJUMS LATVIJĀ}

Enterokoki ir kḷuvuši par vienu no nozīmīgākajiem hospitālo uzliesmojumu izraisītājiem visā pasaulē. Lai gan tie nav tik bīstami kā citas gramnegatīvās baktērijas, tie ir nejutīgi pret daudzām antibiotikām un rezistences gēni var tikt pārnesti uz citām, vairāk virulentām baktērijām - piem. stafilokokiem. Tāpēc îpaša uzmanība tiek pievērsta pret vankomicīnu rezistentiem enterokokiem (VRE). Latvijā VRE parāīijās 2006. gada beigās. Rakstā tiek aprakstīts pirmais dokumentētais multirezistento VRE uzliesmojums Latvijas slimnīcā. 